folk/ed. 2021; 27(2):437-454

DOI: $10.22559 /$ folklor.1554

\title{
Sosyal Sermaye Teorisi ve Sanal Akrabalık Bağları Kapsamında Sivas'ta Kirvelik Kurumu*
}

\section{Institution of Kirvelik in the Context of Social Capital Theory and Fictive Kinships in Sivas}

\section{Emrah Tunç**}

Öz

Sosyal bilimler literatüründe genel olarak insan ilişkilerine gömülü olan kaynak ve potansiyellere gönderme yapacak şekilde kullanılan ve zamanla sosyal teori içerisinde kendisine ait müstakil bir fraksiyon oluşturan "sosyal sermaye" kavramının; normatif bir karaktere sahip olan Marksist toplumsal teorinin yapısal boşluklarını doldurmaya ve insanî ilişkileri merkeze alarak toplumsal pratiğin mahiyetini "sosyal ağlar" üzerinden açıklamaya çalıştığ1 görülür. Bu açıdan "akrabalığın sembolik rolleri üzerine kurulan" ve bireyler arasında dostluk ilişkilerini kurumsal bir örüntüye çeviren "kan kardeşliği" yahut "kirvelik" gibi sanal akrabalık bağlarının, doğrudan sosyal sermaye teorisiyle ilişkilendiği ve içerdikleri kaynaklar yahut diğer sermayelere

Geliş tarihi (Received): 09.12.2020- Kabul tarihi (Accepted): 23.03.2021

* Bu makale, yazarın “Sivas’ta Sünnet Merasimleri ve Kirvelik Kurumu” adlı yüksek lisans tezi kapsamında yer alan bazı verilerin gözden geçirilmesi ve makale formuna uygun şekilde düzenlenmesi suretiyle oluşturulmuştur. Konuya ilişkin ayrıntılı bilgi için bkz. (Tunç 2012). Makalenin dayandı̆̆ı saha araştırması, 2020 yılı öncesinde yapıldığından dolayı söz konusu araştırmaya dair Etik Kurul kararı bulunmamaktadır.

** Arş. Gör. Dr., Sivas Cumhuriyet Üniversitesi Edebiyat Fakültesi Türk Halkbilimi Bölümü.Sivas Cumhuriyet

University, Faculty of Letters, Department of Turkish Folklore etunc@cumhuriyet.edu.tr. ORCID 0000-0001-9764-7326 
dönüşüm potansiyelleriyle, teori açısından oldukça önemli bir çalışma alanı olarak belirdikleri anlaşılır. Bu nedenle bu makalede, Türkiye'nin doğu ve güneydoğu illerinde görülen ve dostluk ilişkilerini kurumsal bir zemine çekerek insanları sıkı sıkıya birbirlerine bağlayan kirvelik kurumunun Sivas kent merkezindeki durumu; sosyal sermaye teorisi üzerinden ele alınmış ve 2012 yılında yapılan saha araştırmasından hareketle söz konusu geleneğin yöre insanı açısından üstlendiği işlevler detaylı bir biçimde tahlil edilmeye çalışılmıştır.

Anahtar sözcükler: sosyal sermaye teorisi, akrabalık, sanal akrabalık, kirvelik kurumu, Sivas

\begin{abstract}
It is seen that the concept of "social capital", which is used in the social sciences literature to reference the resources and potentials, embedded in human relations in general and which over time form a detached faction of its own in social theory, tries to fill the structural gaps of Marxist social theory that has a normative character and explain the nature of social practice through "social networks" by centering on human relations. In this respect, it is understood that fictive kinships such as "blood brotherhood" or "kirvelik", which are based on the symbolic roles of kinship and turn friendship relations between individuals into an institutional pattern, are directly related to social capital theory and appear as a very important field of study in terms of theory with the resources they contain or their potential for conversion to other capital. Therefore, in this article, the situation of the kirvelik institution in Sivas city center, which is seen mainly in the eastern and southeastern provinces of Turkey and connects people tightly by bringing friendship relations to an institutional basis, was discussed through social capital theory and the functions of this tradition for the local people were tried to be analyzed in detail based on the field research conducted in 2012.
\end{abstract}

Keywords: social capital theory, kinship, fictive kinship, institution of kirvelik, Sivas

\title{
Extended summary
}

In the literature of cultural theory, it is seen that the social existence of human beings is often read through the concepts of "capital" and "class". The determinism of economic capital is emphasized by the researchers in a systemic way, accompanied by the normative judgments produced since Marx's theory of historical materialism. In this way, it is understood that the Marxist theory, which generally comprehends human action through class division, is used for a long time in explaining performances and in the analysis of social practice with the dialectics 
of "infrastructure" and "superstructure". However, it has been widely criticized for neglecting human relations or the values embedded in these relationships, along with epistemological transformations in social sciences. Accordingly, the approaches that were used to evaluate the continuity of the system on the axis of human relations by exceeding Marx's materialistic attitude gradually expanded his classical capital theory and added new resources such as cultural capital or social capital, for example, as Bourdieu did. In this respect, although the semantic equivalent is quite old, the concept of "social capital", which has been frequently raised by different disciplines in order to fill structural gaps in classical capital theory, especially over the last quarter of a century, has started to be used in a way that references the resources, and potentials embedded in human relations at the most basic level. Over time, it creates its own detached faction in social theory.

On the other hand, considering that the concept of kinship, which has great importance in terms of social practice, connects people around a specific essence; it becomes clear that kinship is directly related to social capital theory. Moreover, it is seen that fictive kinships such as blood brotherhood or tradition of "kirvelik" (circumcision kinship), which are built on the symbolic roles of real kinship and turn friendship relations between individuals into an institutional pattern, are essentially strategic social practices as attempts to increase the social capital of individuals. Therefore, such ritual connections, which are seen in the disconnected geographies of the world and in many different cultures, appear to be a very important field of study for social capital theory in terms of the resources they contain and their potential for conversion to other capital. That's why, in this article the situation of the institution of kirvelik, which can be read as an attempt to increase social capital, was examined through social capital theory and the functions of this tradition in terms of social life were analyzed in detail based on the field study conducted in 2012.

In this context, it was found that the tradition of kirvelik, which connects individuals by establishing various bonds between families, institutionalizes the relations around certain norms through sharing the expenses of a boy's circumcision ceremony in Sivas city center. Secondly, it is clearly understood that this relationship, established in the context of fictive kinships, functions as a "social loan" at the most basic level and appears as a mechanism that prevents families from the burden of heavy costs of the circumcision ceremony. In this manner, it can be said that families who are relatively far from bureaucracy or state facilities avoid being alone with such social insurance mechanisms and create a new resource for themselves to hope for help in the problems they encounter in everyday life. Thirdly, this tradition, which is treated as a type of relationship which, in most studies in Turkey, is noted to remove the differences between groups, appears as a social practice that emphasizes the differences between people in Sivas. Because people who live in the city center and belong to different religious denominations never resort to this tradition to get close. Due to the systematic implementation of the tradition within groups of "the same color", it is understood that it points to the symbolic boundaries of the community and is made an intermediary in the constructing of identity around a particular axis. Finally, it should be noted that with changing social paradigms or the public rise of individuality, this tradition is increasingly gaining a "reputational" character in Sivas and is no longer a type of strategic 
relationship established to provide visible benefits. In this regard, we can say that this relationship between friends and sometimes relatives, who usually know each other well, is still an institution that is actively used to increase and institutionalize the intimacy between people; however, it is understood that it has become a symbolic relationship that is not very significant for younger generations.

\section{Giriş}

Kültürel kuram literatüründe insanın sosyal varoluşunun, özellikle Marx'ın tarihsel materyalizm teorisinden itibaren sıklıkla "sermaye" ve "sınıf" kavramları üzerinden okunmaya çalışıldığı ve bu doğrultuda üretilen normatif yargılarla birlikte, iktisadî sermayenin belirleyiciliğine sistemli bir şekilde vurgu yapıldığı görülür. Böylelikle insan eylemliliğini genel olarak sınıfsal bölünme üzerinden kavrayan Marksist teorinin, içerdiği "altyapı" ve "üstyapı" diyalektiğiyle performansların açıklanmasında ve toplumsal pratiğin çözümlenmesinde uzun süre kullanıldığı anlaşılır. Ancak çoğunlukla mekanik bir biçimde ve deterministik bir tutumla toplumsalı açıklamaya çalışan bu görüşün; sosyal bilimlerde yaşanan epistemolojik dönüşümlerle birlikte, insanî ilişkileri yahut bu ilişkilere gömülü olan değerleri ihmal ettiği için büyük oranda eleştirilere uğradığı görülmüştür. Bu doğrultuda Marx'ın materyalist tutumunu aşarak sistemin devamlılığını insan ilişkileri ekseninde değerlendirmeye yönelen yaklaşımların, onun klasik sermaye teorisini giderek genişlettikleri ve ekonomik sermayenin yanına; örneğin Bourdieu'nün yaptığı gibi "kültürel sermaye" yahut "toplumsal sermaye" gibi yeni kaynaklar ekledikleri veya bambaşka bir düzlemde, Catherine Hakim'in yaptığı gibi “erotik sermaye” olarak kavramsallaştırdıkları yeni terimleri sistem analizlerine dâhil ettikleri anlaşılır. Bu açıdan söz konusu revize faaliyetleri içerisinde olmak kaydıyla; her ne kadar semantik karşılığı oldukça eskilere dayansa da özellikle son çeyrek asır boyunca klasik sermaye teorisindeki yapısal boşlukları doldurmak amacıyla farklı disiplinler tarafından sıklıkla gündeme getirilen "sosyal sermaye" kavramının; en temel düzeyde insan ilişkilerine gömülü olan kaynak ve potansiyellere gönderme yapacak şekilde kullanılmaya başlandığı ve zamanla sosyal teori içerisinde, kendisine ait müstakil bir fraksiyon oluşturduğu görülmektedir.

Diğer taraftan insan ilişkilerinin temeli sayılan ve toplumsal pratik açısından büyük bir önemi haiz olan akrabalık kavramının; insanları spesifik bir öz etrafinda bağlayan ve onları sistemli şekilde birleştiren bir "bağlantılanma pratiğgi" olduğu düşünüldüğünde, doğrudan sosyal sermaye teorisiyle ilişkilendiği anlaşılır. Dahası "akrabalığın sembolik rolleri üzerine kurulan" (Güç, 2018: 240) ve bireyler arasında dostluk ilişkilerini kurumsal bir örüntüye çeviren kan kardeşliği, ahret kardeşliği veya kirvelik gibi "sanal akrabalık"1 bağlarının da esasında stratejik birer toplumsal pratik olarak bireylerin sosyal sermayelerini arttırmaya yönelik girişimleri oldukları görülür. Dolayısıyla dünyanın birbirinden kopuk coğrafyalarında ve pek çok farklı kültürde görülen bu türden sanal bağlanmaların, içerdikleri kaynaklar ve diğer sermayelere dönüşüm potansiyelleri açısından sosyal sermaye teorisi için oldukça önemli bir çalışma alanı olarak belirdikleri anlaşılmaktadır. Bu nedenle bu 
makalede, asli olarak Türkiye'nin doğu ve güneydoğu illerinde görülen ve sosyal sermayenin arttırılmasına yönelik bir girişim olarak okunabilecek olan kirvelik kurumunun Sivas kent merkezindeki durumu; sosyal sermaye teorisi üzerinden ele alınmaya ve 2012 yılında yapılan saha araştırmasından ${ }^{2}$ hareketle söz konusu geleneğin toplumsal yaşam açısından üstlendiği işlevler detaylı bir şekilde tahlil edilmeye çalışılmıştır.

\section{Sosyal sermaye teorisi üzerine}

En genel anlamıyla "insan sermayesinin bağlamsal tamamlayıcısı" (Burt, 2000: 347) olarak görülen ve ekonomiden başlayarak sosyolojiye veya eğitim bilimlerinden siyaset bilimlerine kadar çok geniş bir yelpazede kullanılan "sosyal sermaye" (social capital) kavramının; Marx'la birlikte ortaya çıkan tek boyutlu "iktisadî determinizm" probleminin aşılmaya çalışılmasıyla birlikte (Man, 2017: 47) özellikle 90’lı yıllardan itibaren sosyal bilimler sahasında sıklıkla gündeme getirildiği görülür. Bu bakımdan farklı disiplinler içerisinde değişik kullanımlara sahip olan terimin, örneğin ekonomi bilimleri kapsamında genel olarak "maddi getiriler elde etmek amaciyla sosyal ilişkiler içerisine gömülü kaynakların kullanımı" veya "sosyal bağlar aracılığıyla erişilebilen kaynaklar" (Lancee, 2012: 17) olarak tanımlandığı ve insan ilişkilerinin market piyasaları açısından stratejik bir noktaya konumlandığına özel bir vurgu yaptığ1 anlaşılır (Lin, 2001: 20). En nihayetinde ise "sürdürülebilir gelişmenin kayıp halkası" olarak ele alınan kavramın, toplumsal ağ düzeneklerinin artı değer üretebilecek bir kapasiteye sahip olduğuna gönderme yapacak şekilde ele alındığı ve bu itibarla sermaye kuramındaki yapısal boşlukların doldurulmasında alternatif bir yaklaşım olarak kullanılmaya çalışıldığı görülmektedir (Sargut, 2006: 5).

Terimi ekonomi bilimlerinin sahasından çıkartarak, sosyolojik analizine dâhil eden ve "kültürel farklılıkların nasıl oluştuğunu, yerleştiğini ve toplumsal tabakalaşmayla ilişkisini" açıklamaya çalışırken ona merkezî bir önem atfeden Bourdieu'nün ise "sosyal sermaye" kavramının yaygınlaşması ve literatüre yerleşmesindeki önemli amillerden biri hâline geldiği anlaşılır (Şan ve Şimşek, 2011: 94; Palabıyık, 2011: 132). Yapısalcı Marksizm’le arasına mesafe koymaya çalışan Bourdieu'nün, bu doğrultuda ekonomik çıkar fikrini maddi amaçların yanı sıra simgesel ya da gayrı maddi amaçları da içine alacak şekilde genişlettiği ve Weber'in din sosyolojisinden faydalanarak, iktisadî ve gayrı iktisadî eylemleri birleştirdiği görülür (Swartz, 2013: 99). Buna bağlı olarak bireyler veya grupların, toplumsal düzendeki hiyerarşik konumlarını korumak ve yükseltmek için çeşitli kültürel, toplumsal ve simgesel kaynakları kullandığını ileri süren Bourdieu'nün (Swartz, 2013: 108); sosyal sermayeyi akrabalık ilişkileri veya ittifak ağları gibi birtakım "network”lerin kişilere sağladığı "kredi hakkı" olarak tanımladığı ve onu "iktidar ilişkileri” ve "çıkar odaklı eylem doktrini” içerisinde ele aldığı anlaşılmaktadır (Bourdieu, 1986: 21-24).

Amerikan gettolarında araştırmalar yürüten ve çalışmalarını genel olarak eğitim alanına yoğunlaştıran James Coleman'ın ise terimin büyük bir etki alanına kavuşmasında diğer herkesten daha fazla pay sahibi olduğu görülür. Bu doğrultuda Bourdieu'nün sosyal sermaye kuramını birtakım ayrıcalıklı bireylerin diğer ayrıcalıklı kişilerle olan bağlantılarını 
kullanarak, hiyerarşik konumlarını korudukları tezine indirgenmesine karşılık Coleman'ın görüşü; bireysel ve kolektif, ayrıcalıklı ve dezavantajlı tüm aktörler için sosyal bağlantıların değerine vurgu yapar niteliktedir. Böylelikle akademik başarı üzerine yoğunlaşarak sosyal sermayenin sadece güçlülerle sınırlı olmadığını, aynı zamanda yoksul ve marjinal gruplara da gerçek faydalar sağlayabileceğini gösteren Coleman'ın, sahip olduğu kavramsal berraklıkla birlikte, özellikle İngilizce konuşulan dünyada terimin kabul görmesinde büyük bir etkisi olduğu anlaşılmaktadır (Field, 2003: 20, 28).

Coleman'dan sonra sosyal sermayeyi toplum düzeyinde bir kaynak olarak ele alan ve onu "ağlar, normlar ve karşılıklı yarar için koordinasyon ve iş birliğini kolaylaştıran sosyal örgütlenmenin özellikleri” olarak tanımlayan Putnam ise İtalya'da sivil dernekler üzerine gerçekleştirdiği çalışmada, demokratik performansın özü olarak gördüğü sosyal ağları bu kapsamda yorumlamaya çalışır. Bu açıdan sosyal sermaye kavramını sivil toplum ağları ya da gönüllü dernekler üzerinden kavrayan ve onu sivil kültüre bağlı bir sermaye biçimi olarak yorumlayan Putnam'ın, genel olarak sosyal sermayenin hayatı kolaylaştıran ve uzlaştırıcı roller üstlenen bir kavram olduğuna vurgu yaptığı görülür (Poder, 2011: 348). Ayrıca diğer önemli isimlerle birlikte terimin sosyal bilimler sahasında popülarite kazanmasına yardımcı olan Putnam'ın, “kavramın tanımlanması, türlerinin belirlenmesi, ölçümü, kapsamının çizilmesi, niteliklerinin belirlenmesi gibi konularda” ve geniş kitleler tarafından tartışılmasında "etkin bir figür” (Şan ve Şimşek, 2011: 96) olarak çeşitli roller üstlendiği anlaşılır³.

$\mathrm{Bu}$ kapsamda özellikle egaliter toplumlar veya bürokratik aksaklıklarla boğuşan insan grupları açısından büyük bir önem arz eden sosyal sermayenin "büyüsü bozulmuş" modern toplumlar açısından da önemli bir kaynak olduğuna işaret eden bu isimlerin; sosyal sermaye kavramını genel olarak kişiler arası ilişkiler ekseninde ele aldıkları ve bu ilişkilerin stratejik bir amaç doğrultusunda kullanılabilecek görünmez bir potansiyele sahip olduğuna özel bir vurgu yaptıkları görülür. Ayrıca çoğunlukla olumlu bir perspektifle ele aldıkları sosyal sermaye kavramını, "güven” ve "dayanışma” kültürü etrafında yorumlayan ve onu "toplumsallaşma"nın kökeninde yer alan önemli unsurlardan biri olarak değerlendiren bu araştırmacıların; sosyal sermayenin hayatı oldukça mekanik bir tarzda yaşayan ve istemsiz yalnızlığa sürüklenen modern bireyler açısından da işlevsel bir çözüm olarak kullanılabileceğine ve bu suretle "sistem kompozisyonu"nu anlamak açısından diğer unsurlarla birlikte dikkate alınması gerektiğine işaret ettikleri anlaşılmaktadır.

\section{Sosyal sermaye teorisi açısından sanal akrabalık bağları ve kirvelik kurumu}

İnsan varoluşunun kökenlerinde yatan "sistematik iş birliği”" veya "organize olmak" gibi kavramların, esasında insanı hayvandan ayıran ve onu doğanın yalın gerçekliğinden çıkararak kültürel bir varlık olma yoluna sokan temel unsurlardan oldukları görülür. Bu bakımdan insanın kurmuş olduğu sosyal bağlantılanmaların, toplumsal yaşamdan söz edebilmek için ve kültürel hayatın ortaya çıkabilmesinde -ayrıca doğal donanımlarıyla ihtiyaçlarını karşılayamayan insanın kültür vasıtasıyla ihtiyaçlarını karşılayabilmesinde- elzem oldukları 
anlaşılır. Bu nedenle antropolojik irfana göre insan olmanın özünü teşkil eden bağlantılanma faaliyetlerinin, özellikle “akrabalık ilişkileri”nden başlamak üzere, insanın edimsel varlığını anlamak amacıyla ortaya çıkmış olan sosyal ve beşerî bilimler açısından temel bir çalışma alanı olarak belirdiği görülmektedir.

$\mathrm{Bu}$ kapsamda en ham hâliyle "siyasal ve ekonomik organizasyonu nispeten basit, sözgelimi yazılı kanunlara dayalı istikrarlı bir devlet yapılanması bulunmayan, sınırı bir teknolojik malzeme ve imkân alanı içerisinde faaliyet gösteren kısmen küçük ölçekli topluluklardan nüfusça kalabalık [...] modern görüngülerle örülü büyük ölçekli topluluklara kadar belirli insanları özel olarak ilişkilendiren bir bağlantılanma teşekkülü ve pratiği” (Enneli, 2016: 12) olarak tanımlanabilecek olan akrabalığın, kültür bilimleri özelinde çoğunlukla "kan yolu" ve "evlilik" vasıtasıyla gerçekleşen bir bağlanma türü olarak ele alındığ1 (örneğin Radcliffe-Brown, 1952: 51 veya Murdock, 1949: 92) ve büyük oranda kültürel bir inşa olarak yorumlandığı anlaşılır. Örneğin akrabalığ “müşterek varoluş” olarak gören Sahlins'in, üreme yollu bağlantılardan ziyade ortak deneyim alanından hareket ederek, akrabaları "birbirlerinin varlığına içkin olan insanlar" olarak tanımladığı görülür (Sahlins, 2015: 12). Diğer taraftan söz konusu içkinliğin, toplumsal rollerin veya hak ve ödevlerin dağıtımıyla sıkı sıkıya ilişkili olduğuna vurgu yapan Holy ise sosyal davranışı anlamanın, akrabalık sistemlerini anlamaktan geçtiğine işaret ederek; böylesi bir müşterekliğin insanların kiminle evleneceğine, nerede yaşayacaklarına, çocuklarını nasıl büyüteceklerine, ihtilafları nasıl çözeceklerine, hangi toprakları ekeceklerine ve ortak çıkarların peşinde kimden yardım bekleyeceklerine etki eden oldukça karmaşık bir bağlantılanma problemi olduğunu ifade eder (Holy, 2016: 44) .

Öte yandan akrabalık ilişkilerini ortak bir özün etrafında insanların birbirlerine bağlanması olarak yorumlayan kültür bilimlerinin; kan bağları (soy/nesep) ve evlilik (hısımlık) yoluyla ortaya çıkan "gerçek" akrabalığın yanı sıra "akrabalığın sembolik rolleri üzerine kurgulanan" (Güç, 2018: 240) "sanal akrabalık” bağlarına da zaman zaman ilgi gösterdikleri ve -her ne kadar yapay olsalar da- içerdikleri yaptırım gücü ve üstlendikleri işlevlerin büyüklüğü nedeniyle bu türden bağlanmaları da akrabalık literatürü içerisine dâhil ettikleri görülür. $\mathrm{Bu}$ açıdan "ne soy çizgisi ne de hısımlık bağı hâsıl olmaksızın kültürel olarak ortaya çıkan [...] yakınlaşmaların akrabalık kurumundaki tezahürü” (Özarslan ve Karataş, 2015: 260) olarak ele alınabilecek olan "sanal akrabalık” bağlarının (fictive/ritual kinship), kültürel kuram literatüründe genel olarak gerçek akrabalık bağlarıyla beraber değerlendirildikleri ve sosyal davranışın anlaşılması açısından bu ilişkilere büyük bir önem atfedildiği anlaşılmaktadır ${ }^{5}$.

Sanal akrabalığı aynı nesepten gelmeyen insanların, aralarında nesep birliği varmışçasına ittifak kurmaları olarak tanımlayan Radcliffe-Brown, bu anlamda söz konusu yakınlaşmanın sadece bağlananlar tarafından değil; tüm toplum tarafından kabul gördüğüne işaret eder (Radcliffe-Brown, 1952: 52-53). Merina kantonlarında tarımsal işbirliğini sanal akrabalık bağları kapsamında mercek altına alan Bloch ise sanal akrabalığın ekonomik işbirliği temelinde şekillendiğine ve bireylere davranışsal açıdan net bir örüntü sunduğuna işaret ederek; böylesi bir yakınlaşmanın üretim tipi açısından insan gücüne bağımlı olan toplumlar nezdinde oldukça önemli olduğuna vurgu yapar (Bloch, 1973: 78). Bu türden yapay 
bağlanmaların sonradan kazanıldıklarına işaret eden Tezcan ise ülkemizde kan kardeşliği, ahret kardeşliği, süt kardeşliğii, musahiplik veya kirvelik gibi isimlerle anılan bu ilişkilerin, sözleşmeye dayalı olduğunu ve mevcut olan dostluk ilişkilerini kurumsallaştırarak, kişilere destek veya güç sağladıklarını ifade etmektedir (Tezcan, 1982: 116).

$\mathrm{Bu}$ bakımdan içerdiği yaptırım gücüyle arkadaşlık veya tanış olma durumundan öteye geçen; ancak nesebe dayalı gerçek akrabalıkların gerisinde kalan bu tarz bağlanmaların, sınıfsal veya etnik açıdan farklı yerlere konumlanmış birey ve aileler arasında kurdukları köprülerle, asli olarak sosyal sermaye kavramı içerisinde değerlendirilmeleri gerektiği anlaş1lır. Zira sosyal sermayenin, her şeyden önce insanlar arasındaki ilişkilere gömülü olan kaynak ve potansiyeller olduğu göz önüne alındığında; sonradan seçme yoluyla ortaya çıkan bu tarz ittifakların, kişilere sağladıkları psikolojik veya maddi faydalarla esasen sosyal sermayenin arttırılmasına yönelik girişimler oldukları görülür. Dahası kimi zaman bir sosyal sigorta mekanizması olarak görev yapan ve kimi zamansa toplumsal dayanışmanın arttırılmasına hizmet eden bu ilişkilerin, verili şekilde elde edilen nesepsel akrabalıktan farklı olarak, pek çok potansiyel ve kaynağa gebe olan stratejik eylemler oldukları anlaşılmaktadır.

Sanal akrabalık bağlarından biri olan kirveliğin ise bu kategori içerisinde yer alan diğer akrabalık türlerine kıyasla, sosyal sermaye kuramı açısından özel bir öneme sahip olduğu görülür. Ülkemizde özellikle Kars, Sivas, Mersin hattının doğusunda kalan ve bu hattı çevreleyen bölgelerde sıklıkla görülen kirveliğin ${ }^{6}$; esasen bir erkek çocuğunun sünnet töreninin yük ve masraflarının, ebeveynleri dışında başka bir kimse tarafından üstlenilmesi yoluyla ortaya çıktığı ve taraflar arasındaki ilişkileri kurumsal bir parantez içerisine alarak aileleri belirli normlar etrafında birbirlerine bağladığı görülür (Kudat, 2004: 11). Böylece kirveliğin, sünnet dügünüyle üstlenilen karşılıklı yükümlülüklerin sonradan hayatın her safhasına yayılmasıyla birlikte; yapay bir ilişki olmasına rağmen geleneğe sahip topluluklar tarafından gerçek bir akrabalık gibi yorumlandığı ve bu hâliyle bireylerin sosyal sermaye artışında büyük roller üstlendiği anlaşılır.

Türkiye'de kirvelik üzerine en kapsamlı çalışmayı yapan ve onun sosyo-kültürel özelliklerini ayrıntılarıyla ortaya koyan Ayşe Kudat; toplumun öğelerini birbirine bağlayan bu geleneğin sosyal sermaye kuramıyla olan bağlantısına özel bir vurgu yapar ve içerdiği semantik yükler açısından kirveliğin; sosyal sermaye mekanizmasının en güzel örneklerinden biri olduğunu dile getirir. Bu bağlamda kirveliğin toplumsal fonksiyonlarını tartışırken onun mevcut dostluk ilişkilerini pekiştiren; devlet denetiminden veya bürokrasiden uzak kalmış yerlerde taraflar arasındaki ilişkileri güvenilir bir zemine çeken; yeri geldiğinde anlaşmazlıkların giderilmesinde veya bazen de politik amaçlar doğrultusunda kullanılan bir uygulama olduğunu söyleyen Kudat; maddi ve bireysel kaynakları az olan grup ve aileler arasında dayanışma yaratan bu geleneğin, en temel düzeyde sosyal sermayenin arttırılmasına yönelik bir girişim olarak okunması gerektiğini ifade eder (Kudat, 2004: 111-114, 185-215).

Benzer biçimde, kirvelik üzerine yapılan diğer çalışmaların ise kirveliğin gerek etnik ve gerek sınıfsal açıdan birbirinden farklı konumdaki aileler arasında uygulandığına özellikle vurgu yaptıkları ve bu suretle belirli normlar etrafında kurumsallaştırılan ilişkilerin, bireyler 
açısından birer kaynak olarak kullanıldıklarına işaret ettikleri görülür (örneğin bkz. Uysal 2016; Tortum, 1979; Türkdoğan, 1966-1969; Balaban, 2002; Kolukırık ve Saraç, 2010). $\mathrm{Bu}$ açıdan bütün bu çalışmaların, sanal akrabalık türlerinden biri olan kirveliğin en temel düzeyde insan ilişkilerine içkin durumdaki simgesel sermayeyle alakalı olduğuna gönderme yaptıkları ve bu geleneği ancak birlikte hayatta kalabilecek insan toplulukları arasında, çeşitli işlevler üstlenen sosyal bir strateji olarak yorumladıkları anlaşılmaktadır.

\section{Sivas'ta kirvelik kurumu}

Çoğunlukla Türkiye'nin doğu ve güneydoğu illerinde görülen ve yöre halkı açısından büyük bir öneme sahip olan kirveliğin; Sivas şehir merkezinde "kivralık" ismiyle anıldığı ve sosyal sermayenin arttırılmasına yönelik bir girişim olarak, geniş kitleler tarafından benimsendiği anlaşılır. Bu bakımdan tıpkı Doğu'da olduğu gibi Sivas’ta da sünnet öncesi çocuğu hamama götürerek onu yıkatan; sünnet esnasında onu "eteğine alan"; ameliyat sonrasında çocuğun yaralarıyla ilgilenen ve bazen düğün masraflarını tamamıyla karşılayıp bazen ise bu masraflara ortak olan; kısacası tören boyunca çocuk ve ailesine maddi-manevi çeşitli destekler sağlayan kimselere (tören babalarına) "kivra" denildiği görülür.

Yurdun geri kalan kesimlerindeki sosyo-kültürel anlamlarına paralel olarak; sünneti kolaylaştırmak ve aileler arasındaki dostluğu pekiştirmek adına uygulanan kirveliğin, Sivas özelinde de benzer bir görüntü sunduğu ve herhangi bir aileye beslenen sempatinin süreklilik kazanması ve bu aileyle olan ilişkilerin kurumsallaştırılması için hayata geçirildiği görülmektedir. Genel olarak babanın yakın arkadaşları yahut aile dostları arasından seçilen kirvelerin, her ne kadar doğu ve güneydoğu illerinde olduğu gibi radikal anlamlara sahip olmasalar da şehir sakinleri tarafından oldukça önemsendikleri ve değer gördükleri anlaşılır. $\mathrm{Bu}$ nedenle aileler arasında büyük bir dayanışma hattı oluşturan ve kişileri birbirlerine ulayarak insan ilişkilerine gömülü olan simgesel sermayeyi ekonomik bir sermayeye dönüştüren kirveliğin, Sivas’ta da büyük bir önemi haiz olduğu görülmektedir.

Bu doğrultuda tıpkı Doğu'da olduğu gibi Sivas’ta da kimin kirve olacağına karar verilirken, kirve adayının aileyle olan ilişkilerinin uzun uzadıya incelendiği ve kirvelik önerisinin ancak detaylı bir tartım sürecinden sonra adaya iletildiği görülür. Böylelikle çocuğuna kirve seçmek isteyen babanın, genelde kendisine denk yahut sınıfsal açıdan üstün olan ailelerden "kivra tutmaya çalıştığı" ve bu itibarla sosyal ağlarına dâhil ettiği yeni akrabasıyla ilişkilerini kurumsal bir zemine çekerek, sosyal sermayesini arttırmaya niyetlendiği anlaşılır. Ancak yine de yapılan görüşmelerden anlaşıldığı kadarıyla, belki de kirveliğin sadece tören babalığıyla sınırlı kalması nedeniyle, söz konusu seçim işleminin Doğu'daki örneklerden farklı olarak normatif hükümler etrafında yapılandırılmadığ 1 ve genel bir kaideye bağlanmadığı görülmektedir:

"Kivra, sünnet olacak çocuğun çok sevdiği bir yakınıdır, akrabasıdır, dostudur. Arkadaşıdır, babasının ahbabıdır yani. Kivralık teklifini ya çocuğunun babası yapar ya da arkadaşı 'ben buna kivra olacam' diye kendisi teklifte bulunur. Aile seçer yani. Ailesinin içine girip çıkabilecek ve yabancısı olmayacak birisidir bu kivra. Bugün herkesin kendi ailesinin örf ve adetlerinin olduğundan dolayı, çoluğunun çocuğunun veya gelen akrabaların rahat davranması açısından herkes tarafından sevilen birisi 
seçilir. Kirve olduktan sonra her iki aile de sanki akraba olmuş gibi birbirlerini sahiplenirler" (Yiğit, 2012).

Sivas'ta kirvelik bağlarının genel olarak belirli bir samimiyete sahip olan yakın arkadaşlar arasında kurulduğu; ancak zaman zaman akrabaların da birbirlerini kirve olarak tuttukları görülür. Diyarbakır, Urfa, Adana, Mardin, Malatya, Tunceli veya Bingöl bölgelerinde kirvelik ilişkisinin, akraba ve hısım arasında kurulamadığı ve yöre halkının bu durumu hoş karşılamadığ 1 görülürken; Sivas'ta bu kuralın pek umursanmadığı anlaşılır. Yapılan görüşmelerde bazı kimseler, kivralık ilişkisinin “dışarı”dan birileriyle kurulmasının daha makbul olacağını söylemekle yetinirken, birçok kimse ise kirvenin -birinci dereceden olmamak kaydıyla- akraba ve hısım arasından da seçilebileceğini dile getirmiştir:

"Yani kivra, akrabalardan, komşulardan da olur. Mesela benim kivram en samimi komşumuzdu yani. Kivra akrabadan da olabilir. Amca, dayı gibi. Ama kivranın dışarıdan olması daha makbuldür. Niye diyeceksin, mesela benim kivram karşı komşumuzdu, ailece gidip gelip çok muhabbet, çok sohbet ederdik. Mesela diyelim ki ben çocukların kivrası oluyorum niye? Daha iyi bir bağ, daha iyi muhabbet, yani bir akraba gibi olma olayı oluyor" (Yekeren, 2012).

Diğer taraftan oluşturduğu kurumsal örüntüyle toplumsal bir birlik havası oluşturan kirveliğin, örneğin Mardin dolaylarında farklı etnik gruplar veya mezhepler arasında kurulduğu görülürken (Güç 2018); Sivas'ta ise farklı mezheplere mensup kişilerin kirvelik bağları kurmakta oldukça tereddütlü oldukları anlaşılır. Bu bakımdan ne kadar yakın ahbap olurlarsa olsunlar; şehirdeki Alevi ve Sünni grupların genel olarak birbirleriyle kirvelik ilişkisine girmemeye çalıştıkları görülür:

"Yani şimdi dediğim gibi, Alevi kardeşlerimde bu olaylar şeydir yani, gelenektir. Alıp verme olmaz onlarda. Hatta ben oğlumun sünnetinde, benim mesela Alevi bir arkadaşım vard1, benim oğlumu sünnet yaptıracaktım, dedim sen kivrasın, benim oğlumun kivrası ol dedim. Bu da kaçtı. Olmadı. En sonunda kızdım, konuşmadım, kardeş dedim bir kivra olacağın filan. Didi ki, sen kivralığın ne olduğunu biliyon mu dedi. Ne var la, oğlanın başını tutuyon, keseceğik işte dedim. Lan oğlum didi, kivralık öyle değil lan didi. Ben senle kivra oldum mu, akraba olmam lazım senle didi. La nasıl oluyor didim. Yook, didi. Bizim kivralık daha başka didi. Yani olmadı çocuk, o mesuliyete girmemek için, olmadı. Ama çok samimi, çocukluk arkadaşım. Olmadı. Yok dedi, ben didi, şeyimiz başka didi” (Çevik, 2012).

Oğlunu sünnet ettirecek bir ailenin kivrası yoksa bu noktada çocuğun babasının iyice düşünerek oğlunun kivralığını yapacak "uygun” birisini bulmaya çalıştığı anlaşılır. Adayın uygunluk kriterlerinin ise en başta maddi imkânları çerçevesinde ve sonrasında ise aileye olan yakınlığı açısından ele alındığı görülür. Bazen ise henüz çocuk kundaktayken yahut daha doğmamışken, sıradan bir şakalaşma esnasında teklifin "oldubittiye getirildiğì" ve bu suretle kirveliğin tesis edildiği anlaşılır. Zaten birbirlerini uzun süredir tanıyan kişiler arasında kurulan kirvelik bağlarının; çoğu zaman kendiliğinden, herhangi bir tarafın resmi teklifte bulunmasına gerek kalmadan oluştuğu görülmektedir: 
"Kivre genellikle tanıdık, eş dost ve çocuğun babası tarafından teklif edilir. Hatta hatta bazan de, çocuk doğar doğmaz, derler ki bazen bu çocuğun, yeğenimin kivresi ben olacağım diye. Ta kundaktan beri onu beklerler. O onun kivresi olur artık" (Üredi, 2012).

Kirvelik ilişkisi kurulmadan önce, şayet öneri babadan adaya gidecekse; adayın maddi durumunun özellikle gözetildiği anlaşılır. Zira adayın kısmen de olsa sünnetin masraflarına katılması beklendiğinden dolayı maddi açıdan iyi durumda olması gerekir. Şayet iyi durumda değilse, babayla önceden anlaşıp hiçbir masrafa katılmayacağını açık bir biçimde belli etmesi gerekir:

"Sünnet masrafları babası tarafından karşılanır. Kirveyle de anlaşmaya bağlı. Mesela kirveye diyorsun, sen kirve olacaksin amma 'ne senden bana, ne benden sana' diye söylenir mesela. Bazıları böyle yapar. Yani ne kirve harcamayı yapar, ne de kirveye karşılık verilir. Eğer kirve harcama yaparsa, sünnetten sonra kirveye hediyeler alınır götürülür. Onun için o da anlaşmaya bağlı. Mesela bizim kirvemize biz söyledik, hiçbir harcama yapmadı, sadece çocuğumu aldı kuaföre götürdü” (Pehlivanoğlu, 2012).

Öte yandan, her ne kadar anlaşmalarla belirtilse dahi kirvenin tören masraflarına bir dereceye kadar katılmak ve en azından çocuğun sünnet giysilerini temin etmekle vazifelendirildiği görülmektedir. Bazen düğün masraflarının tamamını da karşılayabilen kivra, Sivas'ta çoğu zaman masrafların bir kısmına ortak olmakla yetinir. Ancak bütçesinin sınırları içinde çocuğu hamama götürmek, gezdirmek; çocuğa "okkalı" bir hediye almak (bu hediyenin çoğunlukla saat olduğu görülür) kivradan beklenilenler arasındadır. Bazen ise sünnet çocuğunun ana babasına ve kardeşlerine takım elbiseler yaptırdığg görülebilir.

"Kivra çocuğu alır, üstünü başını giydirir, eskiden payton olayları vardı, şimdi arabalarla geziyorlar. Paytona bindirirlerdi mezarlıklara bindirirlerdi, mezarlıkta büyüklere cenaze, dua okunurdu, ondan sonra kivra alır çocuğu hamama götürür, hamamda bir eğlence olur, yani çocuğu götürüyorlar amma, yanı sıra da birçok kişiler de gider, eğlence tertip ederler mesela hamamı kapatırsın, dersin ki yani bizim bir düğünümüz var, çalgısı yiyeceği içeceği, hah kimi alkollü yapar kimi alkolsüz yapar kendilerinin bileceği bir şey”" (Yekeren, 2012).

Bu bakımdan kirvelerin, ailenin birçok yakın akrabasına oranla daha büyük bir sorumluluk altına girdiği görülür. Çocuğun sünnette giyeceği elbiselerin masrafları, merasimden önceki gezdirmelere ait harcamalar veya toplu olarak gidilen hamam ücretinin kivra tarafindan ödendiği, görüşme yapılan hemen herkes tarafından doğrulanmıştır. Bunlar dışında mülakat yapılan kimselerin tamamına yakın kısmı, kivranın sünnet merasiminin masraflarına sadece ortak olduğunu ve bu masrafları hiçbir zaman tek başına karşılamadığını ifade etmiştir:

"Şimdi şöyle. Her şeyi kivra karşılamaz. Kivra bahşişleri karşılar. Mesela hamama gittiler. Tellağa, işte ortaciya filan bunlara bahşiş verir. Sonra sünneti yapmaya gelen sünnetçiye ücretinden başka kabil-i imkânında bir bahşiş verir. Başka, mesela getir götür yapanlar olursa onlara bahşiş verir. Sünnet yemeğini filan kivra karşılamaz. Yemeğini de kivra karşıladıktan sonra kendi oğlunu sünnet ettirsin o zaman, olur 
mu? Ara masraflara iştirak eder. Ufak tefek bazen işte. Haaa, çocuğa en hatırı sayılı hediyeyi alanlardan biri de kivradır. [Ne alır mesela?] Mesela saat alır. Haaa, hatta öyle bir şartlanılmış ki burada, kol saatinin hiçbir hükmünün kalmadığı, gayet de işportaya düştüğü dönemlerde bile çocuklara kol saati alınması devam ediyordu. Zannedersem şimdi cep telefonu filan alıyorlardır. Benim kivram bana saat almıştı mesela” (Arıç, 2012).

Yaptığı masraflar dışında, sünnet esnasında çocuğu tutarak hareket etmesine engel olan kirvenin, çocuğun dikkatini başka yerlere çekerek ameliyatın sağlıklı bir şekilde geçmesini sağladığı anlaşılır. Zaman zaman çocuğa psikolojik destek sağlayarak, ona artık "erkek" olduğunu hatırlatan kirve, çocuğu teskin ve teselli etmeye çalışır.

“Kirvelikte güven itimat önemlidir. Kirve şimdi çocuğu kucağına alır. Sünnetçi keserken çocuktaki önemli olan o pipisindeki mayadan şey yaparsa, çocuğun hayatı gider. Onun için onu çok sağlam tutacak. Onun için en güvenilir, en sadık, en sevecen en babacan insanlar seçilir ki onu ona teslim etsin. Bir çocuk bir babanın canıdır yani” (Koç, 2012).

Aynı zamanda düğüne gelen misafirlerle ilgilenmesi, onları karşılaması ve giderken yolcu etmesi de kivranın asli vazifelerindendir. Gelen misafire kolonya ve şeker tutması, onlara hürmet göstermesi ve kivra olarak ailenin yanında bulunmas1; kısaca manevi desteğini abartılı bir şekilde herkese göstermesi beklenir. Ayrıca gelen altınları ve paraları kaydetmek, çocuğun hemen yanında duran töre kutusuna düğün boyunca sahip çıkmak da yine kivranın görevleri arasında sayılır. Sünnetten sonra çocuk rahatsızlanırsa onu hastaneye götürmek ve çocuğun pansumanlarıyla ilgilenmek gibi görevler de yine kivraya verilmiştir:

\footnotetext{
"Sünnette şimdi mesela kirve başından gitmez onun. Hani yoklamaya geldiler ya, kirve sahip çıkar ortalığa. Misal Mehmet ne getirmiş 10 lira, Hüseyin ne getirmiş 20 lira, bilmem ne getirmiş 30 lira, anlatabiliyor muyum? Kivra yazar onları hep. Ondan sonra da baktın çocuk olur ya, rahatsız oldu. Çocuğu alır doktora götürür muayyene ettirir. Pansuman yaptırır yani. Ben bak halamın oğluna kivra oldum, üç dört kişinin kivrasıyım ben. Bir de sağdıç oldum. Bilirim yani hep" (Takay, 2012).
}

Doğu ve güneydoğu illerinden farklı olarak, Sivas şehir merkezinde -özellikle Sünni gruplar açısından- kivranın görevlerinin sünnet düğünüyle sınırlı tutulduğu ve düğün sonrasında sorumluluğun nihayete erdiği görülür. Bu açıdan aileler arasında kivralık ilişkisinin baki kalmasına rağmen çoğunlukla kivranın görevleri sünnet merasimiyle nihayete erer. Düğün sonrasında ise ailenin kirveye gerçekleştirdiği ziyarette, yanlarında getirdikleri hediyeleri ona takdim ettikleri ve düğün için yaptığı masrafların karşılığını bu yolla ödemeye çalıştıkları görülür. Dolayısıyla Sivas şehir merkezinde kirvelik vasıtasıyla oluşturulan sosyal sermayenin, doğu illerinde olduğu gibi uzun vadeli olmadığı ve kirvenin çocuğun eğitim masraflarına, evliliğine veya diğer ihtiyaçlarına cevap vermek gibi sorumluluklara sürüklenmediği görülür. Ancak çocuğun ve ailenin hayatındaki önemli anlarda, kivranın orada bulunması ve sanal akrabalarına manevi destek vermesi; toplumsal bir beklenti hâline gelmiştir:

"Kivra mesela bayramda çocuğun ziyaret edeceği kapılardan biridir. Onun haricinde çocuğun böyle mühim dönüm noktalarında, kivranın çocuğa bir destek çıkması beklenir. O kadar abartılı değil ama genel itibariyle böyledir. Yani mesela geçen kivrası olduğum 
çocuklar umreye gidiyorlardı. Kivrası olduğum çocuğa çıkarttım bir yol harçlı̆̆ı, bir şeyler vermem icap ediyordu verdim. Ama hani şu da oluyor, şehir hayatı insanın kendi akrabalarına dahi ilgi alakasını belli bir seviyenin altına çektiği için kivralık da o seviyenin altında kalıyor haliyle" (Arıç, 2012).

Bunların dışında Sivas’ta kirvelik bağları nedeniyle oluşan asıl yakınlaşmanın, kirve ile sünnet çocuğu arasında olmak yerine kirve ile çocuğun babası arasında gerçekleştiği söylenebilir. Genel olarak çocukla kirve arasında kurulan bağların "sembolik" ve "itibarî" olduğu ve ikinci dereceden bağlar olarak belirleyici bir karaktere sahip olmadıkları anlaşılır. Bu bakımdan çoğu kez, sünnet çocuğunun büyüdüğünde kivrasıyla olan samimiyetini kaybettiği; buna karşın baba ile kivra arasındaki ilişkilerin çok daha uzun süreli ve yoğun olduğu görülmektedir:

"Yok olmaz. Aha bak ben dün çarşıya gittim. Beni gördü bak inan, hemen karşıma geçti, elimi öptü kirvem nasılsın, iyi misin, hasta mısın? Amma yanıma böyle hiç gelmez. O büyüdü. Bizim eve hiç gelmez. Bir tenecik vardı Yücel, soyadı Ceylan, İstanbul'da şindi, o tabi gelemez hani amma diğerleri burada. Heç birisi yanıma gelmez. Yani dışarıda görünce saygı yaparlar bana, o kadar. Biz asıl babalarılla akraba olmuşuz” (Takay, 2012).

Kirvelik ilişkisiyle birbirlerine bağlanan ailelerin, tıpkı yurdun doğu kesimlerinde olduğu gibi, aralarında kadın alışverişi yapmalarının yasaklandığı görülmektedir. Bu bakımdan Üçer'in de belirttiği üzere, kirveliğin Sivas'taki en büyük yaptırımının iki aile arasında kız alıp vermenin yasaklanması olduğu anlaşılmakladır (Üçer, 1978: 10). Ancak söz konusu dış evlilik kuralının, örneğin Doğu'daki pek çok vilayette ayrıntılı bir biçimde düzenlendiği (yani hangi üyenin hangi üyeyle evlenemeyeceğinin belirlendiği) görülürken, Sivas’ta ise usul ve esaslara dair genel geçer bir kaidenin bulunmadığı anlaşılır. Bu bakımdan görüşmeler esnasında iki aile arasında kız alıp vermenin kirvelik ilişkisiyle birlikte yasaklandığını ifade eden kimselerin, kimin kiminle evlenemeyeceği gibi kompleks bir soruya, daha önceden kafa yormadıkları tespit edilmiştir. Yaşı nispeten küçük olanlar ise böyle bir gelenekten habersiz görünmektedir:

\footnotetext{
“Benim kızım da vardı misal. İstediler. Ben vermedim. Nasıl vereyim, kivrasıyım ben onların. Ben onun çükünü gördüm. Olmaz o iş. Biz ne alırık, ne de veririk (Takay, 2012).

Yasaklanır. Bir ömür sürer bu. Mesela ben seksen yaşındayım. Yedi sekiz yaşındayken sünnet oldum, babam sağdı o zaman. Şu an halen kivramın çocuklarının çocukları var. Onlar bana kivra der, biz onlara kivra deriz. Yani nikâh düşmez. Bizde öyle. Kivranın ne çocuğuna ne kızına, ne gelinine olmaz. Kızı da vardı bi tane, daha sağ ya, gelinleri de bizim evimize gelir, benim döşeğime girerler, yatarlar yani. O kadar, bizim için düşmez" (Yıldız E, 2012).
}

$\mathrm{Bu}$ açıdan kirvelik bağlarıyla birbirlerine bağlanan aileler arasında kız alıp vermenin kesin bir biçimde yasaklanmasının; tüm sembolik ve itibarî görünümlerine rağmen kirveliğin Sivas şehir merkezinde kurumsallaşmış bir örüntü olarak alımlandığına ve insanlar nezdindeki kıymetiharbiyesine işaret etiği anlaşılır. Dış evlilik kuralı nedeniyle kirvenin, evde erkek yokken dahi haneye rahatça girip çıkması, söz konusu kurumsallığın gölgesinde yorumlandığı için toplum tarafından garip karşılanmaz. Bu yüzden yapmış olduğu tören babalığı ile artık ev halkından birisi sayılan kirvenin, suistimal etmemek kaydıyla evin erkeği evde yokken dahi, haneye girip çıkma serbestisine sahip olduğu anlaşılır. 
Son olarak Türk toplumunun zaman içinde geçirdiği değişim ve dönüşümler 1şığında, Sivas'ta sosyal sermayeyi arttırmaya yönelik bir girişim olarak deneyimlenen kirvelik geleneğinin de birtakım değişikliklere uğradığı ve yeni boyutlar kazandığını söylemek mümkündür. Konuya ilişkin olarak Kudat; "Bir toplumun, sosyal, ekonomik ve politik yapısında ortaya çıkan değişiklikler, bu ana-yapı içindeki sosyal kurumları, örf ve töreleri de etkisi altına alır, onların yapısında da kendi fonksiyonlarının gereği gibi işlemesine elverişli gelişmeleri ve değişiklikleri zorunlu hale getirirler” (Kudat, 2004: 219) diyerek modernleşme sürecinde kirveliğin yurt genelinde geçirdiği dönüşümlere işaret eder ve onun yeni şartlara adapte olarak, toplumun ihtiyaçlarına hâlâ cevap verebildiğini ileri sürer. Bu bakımdan gerçekten de Kudat'ın belirttiği gibi, sosyal sermayenin arttırılmasına yönelik bir girişim olarak kirvelik geleneğinin, değişen toplumsal paradigmalarla beraber Sivas'ta da bazı değişikliklere maruz kaldığı ve bu suretle sembolik bir bağa dönüştüğü; ancak itibarî bir görüntü kazanmış olsa dahi geniş kesimler tarafından hâlâ değer gördüğü anlaşılır. Yapılan mülakatlar ışığında, genç neslin kirvelik kurumuna verdiği değerin yaşlı nesle göre bariz bir biçimde azaldığı ve kirvelik hakkında konuşma üsluplarının dahi büyük oranda değiştiği gözlemlenmiştir. Nispeten yaşı büyük olanlar ise kirvelik hakkında konuşurken, genellikle kendileri için önemli bir sosyal sigorta mekanizması olan bu kurumun günümüz şartlarında giderek zayıfladığını hayıflanarak dile getirmiştir:

"Şimdi efendim, pek eski adetler pek eski geleneklerimiz kalmadığı gibi kivralık geleneği de hemen hemen kaybolmak üzere. Maalesef. Yani ben göremiyorum, eskisi gibi saygı kalmadı kivraya" (Üredi, 2012).

"Bizim zamanımızda kivra çok muteberdi. Kivranın hanımı, kızı, gelini, anası, o çocuğa nikâh düşmezdi bizim zamanımızda. Şimdiki zaman düşüyor artık, şimdi önemi kalmadı, kimse dinlemiyor kivrasıymış neyimiş, artık bilmez oldu gençlerimiz” (Yıldız M., 2012).

Ancak her ne kadar gençler açısından sembolik bir hüviyete kavuşmuş olsa da kirveliğin, şehir içerisinde hâlâ büyük bir ısrarla uygulandığının ve örneğin sünnet düğünü davetiyelerinde, ebeveynlerin isimlerinin hemen yanında kirve isimlerine de muhakkak yer verildiğinin özellikle belirtilmesi gerekir.

\section{Sonuç}

Bireyler arasında çeşitli bağlar kurarak onları toplumsalın sınırları içerisine dâhil eden kirveliğin; Türkiye'nin doğu ve güneydoğu illerinde olduğu gibi Sivas'ta da bir erkek çocuğunun sünnet düğününün masraflarının tamamının veya bir kısmının yüklenilmesiyle birlikte, aileler arasındaki ilişkileri kurumsallaştırarak bu ilişkiyi belirli normlar etrafında yeniden yapılandıran ve insanları yapay bir akrabalık ağı içerisine çekerek onları sağlam bir biçimde birbirlerine bağlayan toplumsal bir kurum olarak hayata geçtiği anlaşılır. Bu açıdan insan ilişkilerine gömülü olan kaynakları ortaya çıkaran ve dostluk/akrabalık bağlarını ekonomik bir sermayeye dönüştüren bu uygulamanın, simgesel bağların potansiyel kaynaklar içerdiğine açık bir biçimde işaret ettiği görülür.

Diğer taraftan sanal akrabalık bağları kapsamında kurulan bu ilişkinin, en temel düzeyde “toplumsal bir kredi” olarak işlev gördüğü ve düğünün ağır masrafları altında ailelerin ezilmesini engelleyen bir mekanizma olarak belirdiği anlaşılır. Böylelikle kirvelikle birlikte sosyal sermaye ağına dahil olan taraflar, sınırları toplum tarafından çizilmiş ve nispeten karşılıklılık 
garantisi sunan spesifik bir norm etrafında ekonomik mübadeleye katılarak kurumlaşmış bir ittifak oluştururlar. Bürokrasinin veya devlet erkinin yetişemediği alanlarda kurdukları bu tür sosyal sigorta mekanizmalarıyla yalnız kalmaktan kurtulan ve karşılaştıkları problemlerde medet umabilecekleri yeni bir mecra yaratan ailelerin, hayatın "normal" akışı içerisinde ise kurdukları bu bağ vesilesiyle "toplumsal güven" duygularını pekiştirdikleri anlaşılır.

Ancak kirveliğin özellikle günümüzde, değişime uğramış kimi toplumsal paradigmalar veya bireyselliğin aleni bir biçimde yükselmesi nedeniyle, Sivas şehir merkezinde büyük oranda "itibarî” bir karakter kazandığı ve ülkenin doğu veya güneydoğu kesimlerinden farklı olarak, gözle görülür yararlar sağlamak amacıyla kurulan stratejik bir ilişki türü olmaktan çıktığı anlaşılmaktadır. Genellikle birbirlerini tanıyan ahbaplar ve bazen de akrabalar arasında "tutulan" kirveliğin, taraflar arasındaki samimiyeti perçinlemek ve nispeten kurumsallaştırmak adına hâlâ aktif bir biçimde başvurulan toplumsal bir kurum olduğu; ancak genç neslin "umursamazlığı" nedeniyle giderek sembolik bir ilişki hâline geldiği görülür. Bu açıdan kirveliğin; en azından doğu illeriyle kıyaslandığında Sivas özelinde, sosyal sermayenin arttırılmasına yönelik ancak “sınırlı" bir girişim olarak nitelenebileceği anlaşılmaktadır.

Dahası söz konusu geleneğin, çoğu çalışma içerisinde gruplar arasındaki farklılıkları giderici ve uzlaştırmacı bir ilişki türü olarak ele alındığı görülse de Sivas özelinde değerlendirildiğinde, sistematik olarak "aynı renkten" gruplar içinde uygulanması nedeniyle, esasında insanlar arasındaki farklılıklara vurgu yapan toplumsal bir pratik olarak belirdiği ve bu suretle topluluğun simgesel sınırlarına işaret ederek, kimliğin belirli bir eksen etrafında kurgulanmasında aracı kılındığı görülmektedir.

\section{Notlar}

1 Türkiye'de erken dönem kültür çalışmaları içerisinde (özellikle Nermin Erdentuğ'dan başlamak üzere bazı sosyolojik monografilerde) "tasavvurî akrabalık” olarak adlandırılan söz konusu yapay ilişki biçiminin, bu makalede "sanal akrabalık" terimiyle karşılanması uygun görülmüştür. Zira Arapça bir sözcük olan "tasavvur" yerine, Türkçede "san-“ köküne bağlanan böylesi bir adlandırma, dil evrenimize daha uygun görünmektedir.

2 Burada ancak bir bölümü sunulan saha araştırmasının; 2012 yılının Ekim-Kasım aylarında, yaşları 33 ile 78 arasında değişen ve hayatlarının büyük bir bölümünü Sivas kent merkezinde geçiren 22 kişiyle yapılan görüşmelere dayandığı özellikle belirtilmelidir. Kirvelik ilişkisinin doğu ve güneydoğu illerinin aksine, Sivas’ta büyük oranda ailelerin reisi sayılan erkekler arasında kurulması ve erkeklere kıyasla kadınların bu ilişki biçimi içerisinde sistemli bir şekilde pasif kılınması nedeniyle söz konusu görüşmelerin çoğunluğu (18'i), farklı yaş gruplarından seçilen ve farklı meslekleri icra eden erkeklerle gerçekleştirilmiştir. Ayrıca günümüze doğru gelindiğinde, kirveliğin büyük oranda sembolikleşmesi ve mahiyetini kısmen yitirmesi nedeniyle, geleneğin anotomisinin ayrıntılı bir biçimde betimlenebilmesi için söz konusu 22 görüşmenin 18'i, özellikle 50 yaşın üzerindeki kişilerle yapılmış ve böylelikle tarihsel bir perspektif içerisinden hareket ederek, kirveliğin Sivas kent merkezindeki yaşadığı dönüşümler anlaşılmaya çalışılmıştır. Burada yer almayan görüşme kayıtları ve daha ayrıntılı bilgi için bkz. (Tunç, 2012).

3 Sosyal sermaye kavramının farklı disiplinler ve düşünürler tarafından ele alınış biçimleri ve sosyal bilimler literatüründe kapladığı alan için özellikle bkz. (Field, 2003; Lin, 2001; Fine, 2000).

4 Akrabalığın gündelik hayat içerisindeki rol ve beklentileri belirlemesinin yanı sıra esasında sosyal sermaye kavramı ile de doğrudan ilişkili olduğu görülür. Bu bakımdan örneğin Alan Duben; Kemal Karpat ve Tansı Şen- 
yapılı gibi isimlerin 1970'lerde İstanbul'daki gecekondu semtlerinde yaptıkları saha çalışmalarından hareket ederek, kan bağının bu semtlerde kişilere yüklediği sorumlulukların yanı sıra sosyal sermaye açısından (örneğin iş bulma veya mali yardımlar gibi konularda) büyük kolaylıklar sağladığına işaret eder. Duben'in İstanbul üzerinden yaptığg okumaya dair ayrıntılı bilgi için bkz. (Duben,2012: 83).

5 Sanal akrabalık bağlarıyla ilgili oldukça kapsamlı olan şu eserlere bakılabilir (Lee, 2013; Nelson, 2020). Ayrıca Türkiye'de sanal akrabalıkla ilgili çalışmaları halkbilimi disiplini içerisinden değerlendiren bir makale için bkz. (Ayaz, 2014).

6 Fahrettin Kırzıoğlu, kirveliğin Dağıstan Demirkapısı'ndan Adana'ya ve Tebriz'den Sivas'ın doğusuna kadar olan alanlarda yaygın şekilde görüldüğ̈nü belirtir (Kırzıŏlu, 1953: 504). Türkdoğan ise kirveliği, esasen Sivas ve Adana illerinin doğu kesiminde yaşayan Türkmenlere ait bir gelenek olarak yorumlar (Türkdoğan, 19661969: 199).

\section{Kaynakça}

Ayaz, B. (2014). Türkiye'deki tasavvurî akrabalık ilişkileri konulu çalışmalar üzerine bir değerlendirme.

I. Uluslararası Türk Kültürü Araştırmaları Sempozyumu (TÜKAS) Bildirileri, Nevşehir: Nevşehir Hac1 Bektaş Üniversitesi, 38-44.

Balaban, A. R. (2002). Evlilik akrabalık türleri: Sosyal antropolojik yaklaşım. Ankara: Kültür Bakanlığı.

Bloch, M. (1973). The long term and the short term: The economic and political significance of the morality of kinship. The character of kinship. (J. Goody, Ed.) Londra: Cambridge University.

Bourdieu, P. (1986). The forms of capital. Handbook of Theory and Research for the Sociology of Education. (J. Richardson, Ed) CT: Greenwood, 241-58.

Burt, R. S. (2000). The network structure of social capital. Research in organizational behavior, (B. M. Staw ve R. I. Sütten, Ed.) 22, 345-423.

Duben, A. (2012). Kent, aile, tarih. ( L. Şimşek, Çev.) İstanbul: İletişim.

Enneli, Ç. (2016). Takdim: Akrabalığı sosyal antropoloji üzerinden okumak. Antropolojinin akrabalık yaklaşımları. Ankara: Heretik.

Field, J. (2003). Social capital. London: Routledge (Taylor\&Francis Group).

Fine, B. (2000). Social capital versus social theory: Political economy and social science at the turn of the Millennium. London: Routledge.

Güç, A. (2018). Geçirgen sınırlar: Mardin'de etnik-dini gruplar arasında sanal akrabalık bağları. Akademik Incelemeler Dergisi, (13)2, 237-264.

Holy, L. (2016). Antropolojinin akrabalık yaklaşımları. Ankara: Heretik.

Kırzıoğlu, F. (1953). Kars tarihi. 1, İstanbul: Iş1l.

Kolukırık, S. ve Saraç, İ. H. (2010). Farklı dinî gruplarda kirvelik geleneği: Sanal akrabalığın dönüşümü üzerine bir araştırma, Zeitschrift für die Welt der Türken, 2 (1), 217-232.

Kudat, A. (2004). Kirvelik: Sanal akrabalığın dünü ve bugünü. Ankara: Ütopya.

Lancee, B. (2012). Immigrant performance in the labour market: Bonding and bridging social capital. Amsterdam: Amsterdam University.

Lee, C. (2013). Fictive kinship: Family reunification and the meaning of race and nation in American immigration. New York: Russel Sage.

Lin, N. (2001). Social capital: A theory of social structure and action. Cambridge: Cambridge University.

Man, F. (2017). Çalışma hayatında 'fiziksel görüntü ve sosyal sermaye' ya da 'dördüncü sermaye'. Çalışma İlişkileri Dergisi, 8, (1), 46-61. 
Murdock, G. P. (1949). Social structure. New York: The Macmillan.

Nelson, M. K. (2020). Like family: Narratives of fictive kinship. New Brunswick: Rutgers University.

Özarslan, M. ve H. Karataş (2015). Anadolu Türk kültüründe kadınlar tarafından tesis edilen tasavvurî akrabalıklar. Hacettepe Üniversitesi Türkiyat Araştırmaları Dergisi, (23), 255-270.

Palabıyık, A. (2011). Pierre Bourdieu sosyolojisinde "habitus", "sermaye" ve "alan" üzerine. Liberal Düşünce, Y11 16, (61-62), 121-141.

Poder, T. G. (2011). What is really social capital: A critical review, The American Sociologist, 42, (4), 341-367.

Radcliffe-Brown, A.R. (1952). Structure and function in primitive society: Essays and adresses. Aberdeen: The University of Aberdeen.

Sahlins, M. (2015). Akrabalık nedir, ne değildir? (A. Pala, Çev.) Ankara: Dipnot.

Sargut, A. S. (2006). Sosyal sermaye: Yapının sunduğu bir olanak mı, yoksa bireyin amaçlı eylemi mi? Akdeniz İ.I.B.F. Dergisi, (12),1-13.

Swartz, D. (2013). Kültür ve iktidar: Pierre Bourdieu'nün sosyolojisi. (E. Gen, Çev.) İstanbul: İletişim.

Şan, M. K. ve Şimşek, R. (2011). Sosyal sermaye kavramının tarihsel-sosyolojik arkaplanı. Akademik Incelemeler Dergisi, 6, (1), 88-110.

Tezcan, M. (1982). Tasavvurî akrabalık ve ülkemizdeki uygulama. Ankara Üniversitesi Eğitim Bilimleri Fakültesi Dergisi, (15/1), 117-130.

Tunç, E. (2012). Sivas 'ta sünnet merasimleri ve kirvelik kurumu. Basılmamış Yüksek Lisans Tezi, Ankara: Hacettepe Üniversitesi Sosyal Bilimler Enstitüsü.

Tortum, C. E. (1979). Malatya'da kirvelik. Basılmamış Lisans Tezi, İstanbul: İstanbul Üniversitesi Edebiyat Fakültesi Sosyal Antropoloji ve Etnoloji Bölümü.

Türkdoğan, O. (1966-1969). Türklerde kirvelik ve sünnet geleneği. Türk Kültürü Araştırmalarl Yıllığ III-IV-V-VI, Ankara: Türk Kültürü Araştırma Enstitüsü.

Uysal, Y. (2016). Adıyaman halk kültüründe sünnet merasimi ve kirve kültürünün topluma yansımaları. Turkish Studies, (11/4), 1015-1024.

Üçer, M. (1978), Anadolu'da ve Sivas'ta sünnet gelenekleri ve kirvelik-5. Sivas Folkloru, (66), 12-14.

\section{Kaynak kişiler}

Arıç, Hilmi (2012). 1979 Sivas Merkez doğumlu, Sivas Merkez'de yaşayan kaynak kişiyle 08.11.2012 tarihinde Sivas Merkez'de yapılan görüşme. Görüşmenin ses kayıtları ve deşifre edilmiş metni yazarın arşivindedir.

Çevik, Hatice (2012). 1951 Sivas Merkez doğumlu, Sivas Merkez'de yaşayan kaynak kişiyle 08.11.2012 tarihinde Sivas Merkez'de yapılan görüşme. Görüşmenin ses kayıtları ve deşifre edilmiş metni yazarın arşivindedir.

Koç, Ekrem (2012). 1959 Sivas Merkez doğumlu, Sivas Merkez'de yaşayan kaynak kişiyle 26.11.2012 tarihinde Sivas Merkez'de yapılan görüşme. Görüşmenin ses kayıtları ve deşifre edilmiş metni yazarın arşivindedir.

Pehlivanoğlu, Hasan (2012). 1961 Sivas Karalar Köyü doğumlu, Sivas Merkez'de yaşayan kaynak kişiyle 18.11.2012 tarihinde Sivas Merkez'de yapılan görüşme. Görüşmenin ses kayıtları ve deşifre edilmiş metni yazarın arşivindedir.

Takay, Selahattin (2012). 1948 Sivas Merkez doğumlu, Sivas Merkez'de yaşayan kaynak kişiyle 09.11.2012 tarihinde Sivas Merkez'de yapılan görüşme. Görüşmenin ses kayıtları ve deşifre edilmiş metni yazarın arşivindedir. 
Üredi, Kadir (2012). 1942 Sivas Merkez doğumlu, Sivas Merkez'de yaşayan kaynak kişiyle 27.10.2012 tarihinde Sivas Merkez'de yapılan görüşme. Görüşmenin ses kayıtları ve deşifre edilmiş metni yazarın arşivindedir.

Yekeren, İsmail (2012). 1966 Sivas Merkez doğumlu, Sivas Merkez'de yaşayan kaynak kişiyle 08.11.2012 tarihinde Sivas Merkez'de yapılan görüşme. Görüşmenin ses kayıtları ve deşifre edilmiş metni yazarın arşivindedir.

Yıldız, Emin (2012). 1949 Sivas Porsuk Köyü doğumlu, Sivas Merkez'de yaşayan kaynak kişiyle 09.11.2012 tarihinde Sivas Merkez'de yapılan görüşme. Görüşmenin ses kayıtları ve deşifre edilmiş metni yazarın arşivindedir.

Yıldız, Mahmut (2012). 1933 Sivas Olukman Köyü doğumlu, Sivas Merkez'de yaşayan kaynak kişiyle 17.11.2012 tarihinde Sivas Merkez'de yapılan görüşme. Görüşmenin ses kayıtları ve deşifre edilmiş metni yazarın arşivindedir.

Yiğit, Necati (2012). 1961 Sivas Merkez doğumlu, Sivas Merkez'de yaşayan kaynak kişiyle 08.11.2012 tarihinde Sivas Merkez'de yapılan görüşme. Görüşmenin ses kayıtları ve deşifre edilmiş metni yazarın arşivindedir.

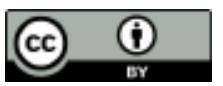

$\mathrm{Bu}$ eser Creative Commons Atıf 4.0 Uluslararası Lisansı ile lisanslanmıştır.

(This work is licensed under a Creative Commons Attribution 4.0 International License). 